University of Chicago Law School

Chicago Unbound

Journal Articles

Faculty Scholarship

1947

\title{
True Meaning of the Constitutional Prohibition of Ex-Post-Facto Laws
}

William W. Crosskey

Follow this and additional works at: https://chicagounbound.uchicago.edu/journal_articles

Part of the Law Commons

\section{Recommended Citation}

William W. Crosskey, "True Meaning of the Constitutional Prohibition of Ex-Post-Facto Laws," 14 University of Chicago Law Review 539 (1947).

This Article is brought to you for free and open access by the Faculty Scholarship at Chicago Unbound. It has been accepted for inclusion in Journal Articles by an authorized administrator of Chicago Unbound. For more information, please contact unbound@law.uchicago.edu. 


\section{THE}

\section{UNIVERSITY OF CHICAGO LAW REVIEW \\ VOLUME 14 \\ JUNE 1947 \\ NUMBER 4}

\section{THE TRUE MEANING OF THE CONSTITUTIONAL PROHIBITION OF EX-POST-FACTO LAWS*}

\section{WIILIAM WinsLOW CrossKey $\dagger$}

1

HE "ex-post-facto" clause of section Io of Article I of the Constitution provides flatly that "no State shall pass any ex post facto Law." In the ninth section of the same article, there is a similar provision which applies to Congress. It is thus evident that "ex post facto Laws," whatever they are, were thoroughly disapproved by the framers of our government and were intended by them to be completely impossible under our system.

Literally, "an ex post facto Law" is simply a law that is retrospective; that is, a law made after the doing of the thing to which it relates, and retroacting upon it. Such laws are generally deemed unfair, because, in the nature of the case, the person, or persons, involved in the behavior to which such a law relates, can have had no notice, when the behavior took place, of such an after-made law which applies to it. The unfairness varies, however, from case to case. It is non-existent in cases of the doing of heinous things in reliance on legal technicalities; in other cases, supervening unforeseen events may give rise to equities which wipe any unfairness out; and the public welfare sometimes demands that legislation be passed, which, in some measure, disregards individuals' strict antecedent rights.

When the Constitution was formed, there were not many men, apparently, who agreed with these views of this subject. There were a few, however, who held such opinions; and of these, George Mason, of Virginia, one of the delegates of that state in the Federal Convention, is the

* This article will form a chapter in a forthcoming book, "Politics and the Constitution: A Story of Distortion, Misconception and Misconstruction, in our Fundamental Law."

$\uparrow$ Professor of Law, University of Chicago Law School. 
best known example. Mason protested vigorously, in the course of the Convention's proceedings, the extreme unwisdom of inserting in the Constitution the two absolute prohibitions of all "ex post facto Laws" which the document contains. "There never [had been], nor c[ould] be, a legislature," he said, "but must, and w[ould], make such laws, when necessity and the public safety require[d] them." The provisions forbidding them to both "the general and the state legislatures" would make them "a breach of all the constitutions in the Union," for the future. Yet such laws would be made, and enforced, Mason predicted; and thus "precedents" would be created "for other innovations," which would weaken and perhaps destroy the Constitution. The eminent good sense of Mason's views, and the absolute accuracy of the predictions he made, events were soon to prove; but though he exerted every effort to induce the Convention to alter the sweeping prohibitions against which he protested, his efforts were in vain. ${ }^{x}$

The difficulty was that the country had just been through a period when the making of "ex post facto Laws" had been greatly abused in many of the states. The extreme dishonesty of some of the laws they had passed, like the so-called "pine-barren law" of South Carolina, or the papermoney acts of Rhode Island, had disgusted too many honest men. Yet, in spite of the recency of this experience, many of the leading delegates in the Federal Convention were, at first, of the opinion that no restriction against "ex post facto Laws" was needed. "There was no lawyer, no civilian," said Oliver Ellsworth, of Connecticut, "who would not say that [such] laws were void of themselves." William Samuel Johnson, of the same state, and Gouverneur Morris and James Wilson, of Pennsylvania, also took this view; but Daniel Carroll, of Maryland, undoubtedly spoke the more general sentiment. "Experience overruled all other calculations," he said, "[and] in whatever light ['ex post facto Laws'] might be viewed by civilians or others, the State Legislatures had passed them, and they had taken effect." He thought, therefore, that the making of such laws ought to be prohibited; and as the Constitution shows, the making of them was prohibited absolutely, both to the nation and the states. ${ }^{2}$

The nature of the prior state acts to which Daniel Carroll referred, and the sense in which, it is plain, the "ex-post-facto" clauses were intended and understood, are plainly disclosed in the newspapers of the time. An item on the subject, which appeared in The [Philadelphia] Freeman's Jour-

× 2 Farrand, The Records of the Federal Convention of 1787 , at 640 (I937); 4 Ibid., at 59 .

22 Ibid., at 375-76, 435, 439-40, 440 n. $x 9$. 
nal, on the 7 th of September 1785 , and was afterwards reprinted in The American Museum, a monthly that circulated among all the states, undoubtedly exhibits what the general understanding was, at the time when the "ex-post-facto" clauses were drawn. The item is short; and since it also contains evidence of the nature of the antecedent abuses intended to be cured, it seems worthwhile to quote it for the reader entire:

\section{ON EX POST FACTO LAWS}

It is pretty generally agreed, that a total want of confidence pervades the united states, both as to the public, and the citizens individually. Various causes, some obviously just, have been assigned to account for this effect: and every person seems to know, why money, in particular, is no longer to be obtained at legal, or, indeed, any other interest, in the way heretofore practised-that is, by mortgage or bond. But I have not, yet, seen any expedient assigned, for restoring private confidence, and usefully diffusing the goods of fortune, otherwise confined to a few, among the people at large. I will endeavour to point out one.

The privilege of making ex post facto laws, has, unfortunately for our political character, been but too generally assumed by the different legislatures in the united states; and it is with astonishment I view, in the retrospect, certain transactions, under this dangerous and impolitic assumption. To suffer a continuation of this shameful abuse of power, would be to hold our patrimony and liberty as tenants at willan odious tenure! Distrust, the canker-worm of prosperity and happiness, must haunt that government which tolerates the abuse; and gnaw deep into every measure, public or private, in its nature.

Where is the man, who, possessed of a sum of money, though unprofitably locked up in his chest, will choose to trust it abroad-if an omnipotent legislature can set aside contracts ratified by the sanction of law, and order that, which was lent in gold and silver, to be paid in paper, or what else they please, or of what value?

Without pretending to more than a common share of political pathology, I may venture to say, that ex post facto laws are poison to free constitutions, and pregnant with calamity to the community. No credit can exist, where the practice obtains. A tender law, for instance, should never extend to contracts already made. If the legislatures throughout the union, were to pass acts declaratory of the illegality, and dangerous tendency of all ex post facto laws, I think it would prove a preventative to further evils; restore lost confidence; and give a scope to the exertions of the industrious, who would thus be enabled to borrow, as formerly, money to prosecute their different avocations. The farmer might then plough his land-the mechanic improve his art-and the merchant turn the balance of trade in our favor. Fair science would raise her head; and thus the body politic would draw increasing vigor from the thriving strength of its limbs.

\section{RUSTICUS $^{3}$}

${ }_{2} 2$ The American Museum 169 (Aug. I787). A list of the subscribers to The American Museum will usually be found printed in the opening pages of the bound volumes. The item, "On ex post facto laws," was likewise published in The [Charleston, South Carolina] Columbian Herald, on November 26, I785. 
Though the foregoing item was one of the earliest of its kind to appear during the post-Revolutionary business depression, which gave rise to most of the discussions of "ex post facto Laws," there were a few references to such laws which were earlier. Thus, in The [Charleston] SouthCarolina Gazette and General Advertiser, of June $17, I_{7} 83$, a proposal was made, long before the depression had begun, that a law should be passed to recompense all American merchants who might be compelled, under the treaty of peace with England, to pay their debts to their British creditors in specie, if they could show that they had previously been compelled, under American war-time paper-money laws, to accept payment of their own debts in, or sell their merchandise for, paper. The maker of this proposal, who signed himself "Hampden," agreed that such a law would be "an ex post facto Law;" but it would, he said, nevertheless be "founded in equity and reason." Several other items exhibiting this same understanding of "ex post facto Laws" appeared in The [Trenton] Neve-Jersey Gazette, and The [Philadelphia] Freeman's Journal, during $1784 .{ }^{4}$ At that time, the post-Revolutionary business depression had hardly begun. Later, when it was more advanced, and "ex post facto Laws" became common, references to the subject were frequent.

Thus, on the 4 th of January 1786 , a typical item appeared in The [Elizabeth-Town] Political Intelligencer and New-Jersey Advertiser. "Does not justice require, and equity demand," this item asked, "that no law passed subsequent to a contract shall operate upon, or in any ways effect [sic] a bona fide agreement prior to it? Ex post facto laws, those engines of oppression, are only admissible in case of apparent fraud; where combinations are formed against the general good, through some defect or oversight in a law, evidently intended indeed, but not adequate to prevent the mischief." Another item of a similar kind appeared in The [Trenton] New-Jersey Gazette, about three weeks later. Attacking the many recent "acts for the relief of insolvent debtors," it declared that there could have been no objection to these acts if only they had not been "made ex post facto; that is to say, operating as to debts contracted previous to their passing."

At about the same time these items were appearing in New Jersey, Pierce Butler and Charles Cotesworth Pinckney, in South Carolina, two of the state's future delegates to the Federal Convention, were using the term "ex post facto Laws," in debates in the local legislature, in exactly

"See "Scipio" and "Lycurgus" (the latter from The [Philadelphia] Freeman's Journal), in The [Trenton] New-Jersey Gazette, of March 2, and November x, I784, respectively.

5 "Probus" in the issue of January 30, 1786. 
the same way. On the 3 Ist of January I 786 , General Pinckney moved, in the South Carolina House of Representatives, that the accounts of two soldiers be received, "who," he said, "belonged to the regiment he had [had] the honor to command [during the Revolution]." He admitted that a resolution of the House stood in the way, which had been adopted by that body on the 4th of February I785. It "restricted the auditor from receiving any accounts after a limited time," which, the General admitted, was "now expired." "[But] the resolution [fixing this limit] was," he said, "really an ex post facto law that ought not to sway the House [in its consideration of his motion]."6

Major Butler's remarks were made in opposition to a proposal, put forward on the 28th of February, to change retrospectively the table of depreciation for the state's paper-money issues. "Th[e] proposition," said Butler, "went to introduce an ex post facto lar; if so, it was unjust and impolitic; opening a door for promoting disorder and confusion, in a time of peace and tranquillity." 7 In the course of the debates, two other prominent South Carolinians, Edward Rutledge and Judge Henry Pendleton, also used "ex post facto Law" in this same way. ${ }^{8}$ And in the local newspapers, the term appeared in other connections, unchanged in sense, from what, we have already seen, it had had in the Charleston papers, in $1783^{\circ}$

In New England, despite the severity of the depression there, "ex post facto Laws" were longer in coming; but when they came, the mode of reference to them was the same. A squib that appeared in The [Boston] Massachusetts Centinel, when a tender act was first proposed, pointed out that, "unless the act operated ex post facto, [the people of the state might] as well pay [their] honest debts." ${ }^{\prime \prime}$ And after the act was passed, an item in The [Boston] Independent Chronicle sarcastically noted that "the legislature of the Commonwealth [had] passed an act "for the suspension of law,' as they called it." "But be the name what it may," the item went on, "the bill [is] evidently a tender act, and the assumption of a power to dispose byan ex post facto lare, of the private contracts made between man and man." II

To the foregoing, there may be added a rather widely copied item which appeared in The Massachusetts Centinel, after the Constitution had come

6 The [Charleston] South-Carolina Gazette \& General Advertiser (Feb. I, I786).

7 Ibid., March 2, 1786.

${ }^{8}$ Ibid., March 2, 8, 1786.

9 "A Friend to Justice," The Charleston [S.C.] Morning Post (March 15, 1787).

so February II, I 786 .

${ }^{2 x}$ May 3I, I787. 
before the people. It took the position that the comprehensive character of the two "ex-post-facto" clauses contained in that document was one good reason for its prompt ratification. "The 24th article of our own [Massachusetts] bill of rights declares," said the item, "that laws made to punish for actions done before the existence of such laws, \&c., are unjust. This relates then to ex post facto laws in criminal prosecutions: But our state bill of rights is silent as to any ex post facto lawes which relate to proper$t y$, and civil prosecutions; though it must be confessed that such laws are as much against the nature of government as those relating to crime. The federal constitution has accordingly guarded against such lares, and clearly, because some states, of which our own is one, have not observed such a restriction." Thus, the Constitution added to the security which the Massachusetts bill of rights had previously provided-a point, the item concluded, which was distinctly in the Constitution's favor..$^{.2}$

The foregoing item from The Massachusetts Centinel appears to have been the only one published during the ratification campaign, that gave any real indication as to how the "ex-post-facto" clauses of the Constitution were understood. The other newspaper and pamphlet references to these clauses (which probably seemed to require no comment) were indeterminate in character. The best known of these is that by James Madison in the forty-fourth number of The Federalist. Referring to the prohibitions against "bills of attainder, ex-post-facto laws, and laws impairing the obligation of contracts" as constituting collectively a "constitutional bulwark in favor of personal security and private rights," Madison declared that the measures prohibited were "contrary to the principles of the social compact, and to every principle of sound legislation." These statements, there can be little doubt, were carefully contrived to distract attention from the "contracts" clause, which by no means answered, in the entirety of its coverage, to the whole of Madison's description. Another effort, apparently of the same kind, was contained in a letter which Roger Sherman and Oliver Ellsworth, of Connecticut, wrote on the 26th of September 1787 , a few days after the Federal Convention had adjourned. "The restraint on the legislatures of the several states respecting [the] impairing [of] the obligation of contracts by ex post facto laws, was thought necessary," they said, "as a security to commerce." "r3 What ef-

12 The Massachusetts Centinel (Nov. 28, 1787). Among the papers which copied this item were The [Portland, Maine] Cumberland Gazette (Dec. 13, 1787 ) and The [Newburyport, Massachusetts] Essex Journal (Dec. I2, 1787). There were some others; but a tally of them was not kept.

${ }^{x_{3}} 3$ Farrand, op. cit. supra note $I$, at 99, 100. 
fect, if any, a statement like this may have had upon the contemporary understanding of the "ex-post-facto" and "contracts" clauses is difficult to say. It is clear, however, that neither it nor Madison's statement in The Federalist was really contradictive of the view of "ex post facto Laws" which then was generally current; and since the interpretation of the "ex-post-facto" clauses, in The Massachusetts Centinel, was in accord with the established view, and nowhere attacked, it seems proper to conclude that the view in the Centinel was that generally entertained as to the meaning of the "ex-post-facto" clauses, at the time.

The conclusion just stated is fortified by many other considerations. One of these is, that, if any curious American of ${ } 787$ had turned to the law books then, and before that time, in use, he would have found that the usage in them, of the words of the "ex-post-facto" clauses, was in precise accord with the view of those clauses which The Massachusetts Centinel had published. If he had turned, for example, to Giles Jacob's Law Dictionary, of 1739 , the standard work of its kind in the eighteenth century, he would have found that Jacobs defined the phrase "ex post facto," with complete generality, as "a Term used in the Law, signifying some Thing done after another Thing that was comitted before"; he would have found, also, that Jacobs illustrated the use of the term, with examples drawn from the civil branches of the Common Law; and he would have found no mention at all, by Jacobs, of any use of the term, in reference to criminal matters. ${ }^{14}$ In short, it would have seemed to any one who had referred to Jacobs, that the most important use, and the usual use, of the term "ex post facto" was in reference to civil, rather than criminal affairs; and, as we have seen, the antecedent American newspaper usage tends to suggest this conclusion, too.

If, in addition to Jacobs, our inquiring American had looked at the decided cases, he would have found Lord Raymond, in I724, referring to a certain act of Parliament of $I 720$, as "an ex post facto act," in its requirement that certain prior contracts should be registered as a condition precedent to recovery upon them. ${ }^{\text {Is }}$ And had he looked at legal textbooks, he would have found in such standard works as Sheppard's Touchstone, from the seventeenth century, repeated instances of the use of the term "ex post facto" as Jacobs defined it; ${ }^{16}$ he would have found the same thing

$x_{4}$ The examples given by Jacobs are that "an Act done, or Estate granted, may be made good by matter $e x$ posi facto that was not so at first, by Election, \&c.," and that "sometimes a Thing well done at first, may afterwards become ill [in the same way]."

Is Wilkinson v. Meyer, 2 Ld. Raym. I350, I352 (I724).

${ }^{16}$ I Sheppard, Touchstone of Common Assurances 63, 67, 68 (7th ed., I820); 2 Ibid., 234, $250,267,372$. 
in more recent works, like Fearne on Contingent Remainders, of $177^{2,}{ }^{17}$ or Powell on Devises, of $I 788 ; ;^{18}$ and he would have found that the usage in the systematic commentators, like Blackstone and his successor, Wooddeson, was similar.

Yet, in spite of this fact, both Wooddeson and Blackstone actually were cited, at a later date, to justify the view which came eventually to be accepted: that "ex post facto Laws" means "retrospective criminal statutes only." The passage in Wooddeson which is supposed to justify this is a simple statement that "justice wears her sternest aspect" in the case of "penal statutes passed ex post facto."x The statement, obviously, does not warrant the inference which the proponents of the limited view of the "ex-post-facto" clauses insisted on drawing from it; and the passage from Blackstone, also relied upon to the same purpose, is likewise devoid of evidence to such an effect.

The Blackstone passage comes from his chapter entitled "Of the Nature of Law in General." In the course of his discussion, Blackstone referred to the necessity of "prescription," or "notification," in some form or other, in the case of all laws. It was incumbent upon a government, he said, that this step in law-making should be accomplished "in the most public and perspicuous manner; not like Caligula, who (according to Dio Cassius), [had] wr[itten] his laws in a very small character, and hung them up upon high pillars, the more effectually to ensnare the people." "[But] there was," said Blackstone, "still a more unreasonable method than this, which [was] called making of laws ex post facto; when $a f t e r^{20}$ an action (indifferent in itself) is committed, the legislator then for the first time declares it to have been a crime, and inflicts a punishment upon the person who has committed it." "Here," said he, "it is impossible that the party could foresee that an action, innocent when it was done, should be afterwards converted to guilt by a subsequent law; he had therefore no cause to abstain from it; and all punishment for not abstaining must of consequence be cruel and unjust." "All laws should be therefore made," he concluded, "to commence in futuro, and be notified before their commencement; which [was] implied," he said, "in the term 'prescribed.'" In this passage, it seems quite clear, Blackstone was merely exemplifying the "making of laws ex post facto," and not defining such laws. If there could be any doubt about this, based on his mode of introducing his example, the

\footnotetext{
${ }_{77}$ Fearne, An Essay on Contingent Remainders 274, 362 (8th ed., I824).

${ }^{18}$ Powell, An Essay upon the Learning of Devises Ir3, I33, I34 (I788).

92 Wooddeson, A Systematical View of the Laws of England 64I (I792).

${ }^{20}$ Blackstone's italics.
} 
conclusion he drew from that example, that "all laws"-not merely all criminal laws-"should be therefore made to commence in futuro," surely ought to set that doubt at rest. For, in the light of this conclusion, the passage affords no support for the view for which it has frequently been cited; and if it did afford support for that view, it would be unique among the evidence of current and prior usage..$^{2 x}$

The first intimation that the "ex-post-facto" clauses of the Constitution had been intended to relate to criminal statutes only, was made in the Virginia ratifying convention, early in the summer of $\mathrm{x} 788$, after the requisite nine states had already approved that document. This improbable contention as to the intended meaning of the "ex-post-facto" clauses was eventually supported by Edmund Randolph; but it was made, in the first instance, in an outright way, by James Madison. Madison was in a hole, at the time, into which he had fallen through his own over-confidence and maladroitness, in answering certain arguments of Patrick Henry's. Henry had interpreted the "ex-post-facto" clauses as they had been interpreted in the preceding fall, by the writer in The Massachusetts Centinel. Unlike that writer, Henry, however, had undertaken to question the "wisdom" and "good policy" of these provisions. "If no ex post facto lawes [can] be made," he asked, "what is to become of the old Continental paper dollars? Will not this country be forced to pay in gold and silver, shilling for shilling? Gentlemen may think that this does not deserve an answer. But it is an all-important question, because the property of this country is not commensurate to the enormous demand."

Apparently, "gentlemen" did consider that these and others of Henry's views deserved an answer; and in the course of a long speech for that purpose, Edmund Randolph sought to suggest, without actually saying so, that the "ex-post-facto" clauses of the Constitution applied to criminal statutes only. Many other things were said of many other matters, with the object presumably of blurring the issue. The masterful Henry was not to be fobbed off, however, by any such trick. "Lament[ing] that he could not see with that perspicuity [sic] which other gentlemen were blessed with," Henry repeated the fear he had before expressed, that, because of the two "ex-post-facto" clauses, Virginia "would be obliged to pay for her share of the Continental money, shilling for shilling." And he asked "gentlemen who had been in high authority," whether it was not true that "there [had been] some state speculations on this matter." "He had been informed," he said, "that some states had acquired vast quantities of that money, which," he again insisted, "they would be able to recover," by

${ }^{2 x}$ I Bl. Comm. 46. 
reason of the "ex-post-facto" clauses, "in its nominal value, of the other states." This intimation, to an assemblage of Virginians, whose one rule of life was to put their every shilling into land and slaves, was damaging to the Constitution in an extreme degree. Henry simply had to be answered; and James Madison, one of those to whom Henry's insinuating questions were addressed, confidently undertook to do so.

Madison would not deny that "there might be some speculations on the subject." Confident, indeed, that he had a devastating answer for Henry's argument, Madison even confessed his own belief that "the old Continental money was settled [as between the states,] in a very disproporbionate manner." But of what consequence was that, when "there was a clause in the Constitution which cleared [this matter] up?" That clause, said Madison, was "the first clause of the 6th article." "[It] provide[d] that 'all debts contracted, and engagements entered into, before the adoption of th[e] Constitution, sh[ould] be as valid against the United States, under [the] Constitution, as under the Confederation." "[This] meant," Madison confidently explained to his hearers, "[that] there should be no change with respect to claims, by th[e] political alteration [which the Constitution would effect]; and that the public would stand, with respect to their creditors, as before." For his part, he candidly confessed that he thought "the validity of claims ought not to diminish by the adoption of the Constitution. But, however [that might be], it could not [, in the light of the clause he had quoted,] increase [them]." Triumphant in the belief that he had refuted Henry's argument, Madison sat down.

The opening thus gratuitously presented could not, of course, be passed up; and George Mason, who, we have seen, had attacked the wisdom of the sweeping "ex-post-facto" clauses, in the Federal Convention, rose to the attack. To Madison's injudicious testimony that the Continental money was held "very disproportionately" as between the states, Mason added his own as that, no doubt, of another "gentlemen who had been in high authority." "He had been informed," he said, "that some states had speculated most enormously in this matter. [And, in addition,] many individuals had speculated so as to make great fortunes on the ruin of their fellow-citizens. The clause which ha[d] been read [by Madison] as a suffcient security, seemed to him to be satisfactory as far as it went; that is, that the Continental money ought to stand on the same ground as it did previously, [in the sense] that the claim should not be impaired." This the reader will note, is what the clause actually said: the claims were to be "as valid" as before, and nothing was said that precluded the possibility that through some other provision of the Constitution they might be more 
so. "Under the Confederation," Mason accordingly went on, "there were means of settling the old paper money, either in Congress or in the state legislatures. . . . They could discharge it at its depreciated value. [Was] there that means [left in the Constitution]?" His answer was that, by the express terms of the document, "neither the state legislatures nor Congress c[ould] make an ex post facto law. The nominal value must therefore be paid." "Where [was] the power in the new government," he demanded, "to settle this money so as to prevent the country from being ruined? If there [was] any real security against this misfortune, let gentleman show it. [He could] see none. The [ex post facto] clause d[id] away the pretended security in the clause which [had been] adduced by the honorable gentlemen. This enormous mass of worthless money, which ha[d] been offered at a thousand for one, must be paid in actual gold and silver at the nominal value."22.

As the reader will perceive, Madison stood refuted, and he was, of course, obliged to attempt some kind of answer. His answer consisted, in the main, of a vain repetition of what he had said before. In addition, he had, however, to say something of the "ex-post-facto" clauses; and of them, he affirmed, though so weakly he "could not be heard" by the reporter, ${ }^{23}$ that, in the Convention at Philadelphia, "ex post facto laws" had been "interpreted" as relating to criminal cases solely.24 The presumptive basis for this statement, recorded only in Madison's own notes, was actually inadequate to support the statement which Madison made, ${ }^{25}$ and the weakness of his delivery in all probability resulted from that fact, and from his poignant awareness of the inherent improbability, to the minds of his hearers, of the supposed fact which he affirmed.

When Madison had finished, Patrick Henry arose and said: "Mr. Chairman, I am convinced, and I see clearly, that this paper money must be discharged, shilling for shilling. The honorable gentleman must see better than I can [about the views at Philadelphia], from his particular situation and judgment [as a member of that convention]; but this [matter now before us] has certainly escaped his attention." "Scaling the money," Henry once more confidently insisted, was prevented by the "ex-postfacto" prohibitions. "[The state legislatures'] hands [were] tied up, by [the] clause [in section Io]; and in the [ninth] section, there [was] a clause that

${ }^{22} 3$ Elliott, The Debates in the Several State Conventions on the Adoption of the Federal Constitution $46 \mathrm{I}-73$ passim (2d ed., 1836 ).

23 Ibid., at 473 .

24 Edmund Randolph repeated this part of what Madison had said, which the reporter did not hear. 3 Ibid., at 477 .

${ }_{25} 2$ Farrand, op. cit. supra note I, at 448 ; cf. ibid., at $440,636,640$. 
prohibit[ed] the general legislature from passing any ex post facto law; so that the hands of Congress [were] tied up, [too]."

The triumphant character of Henry's remarks is proof enough that Madison's weakly delivered statement about the views at Philadelphia had not had a convincing ring; and this fact is further indicated by the circumstance that Edmund Randolph felt called upon at this point, to come to Madison's assistance. "Ex post facto laws, if taken technically, relate[d] solely to criminal cases," he said. And that this was true of the clauses in the Constitution was proved, he argued, by the fact that such laws were prohibited therein in context with bills of attainder. This weak contention, absurd in the light of the many heterogeneous groupings which the Constitution contains, is itself evidence that Randolph was hard-pressed. He also said that "the technical meaning which confined [ex post facto] laws solely to criminal cases was followed in the interpretation of treaties between nations, and was concurred in by all civilians." No "civilians" were cited, however; and the revered Blackstone, so much relied upon in after years, and, according to the notes of Madison, cited in the Federal Convention, was not even mentioned. Randolph, it is also of interest to note, did not actually corroborate Madison on the views at Philadelphia: he observed merely that his "honorable colleague" had said that the "ex-postfacto" clauses had been interpreted there, as he, Randolph, declared they technically should be.

When Randolph had finished, George Mason arose and "beg[ged] leave to differ from [Randolph and his technical meanings]." "Whatever [an ex post facto law might] be at the bar, or in a professional line, I conceive," said Mason (who was not a lawyer), "that, according to the common acceptation of the words, ex post facto laws and retrospective laws are synonymous terms." Was the Virginia Convention, then, "to trust business of this sort to technical definitions? The contrary [was] the plain meaning of the words." "[And] when this [should] come up before the federal judiciary, they must determine according to [the] Constitution. [The Constitution] sa[id], expressly, that [neither Congress nor the state legislatures] sh[ould] make ex post facto laws. [And] whatever $\mathrm{m}$ [ight] be the professional meaning, yet the general meaning of ex post facto law [was] an act having a retrospective operation. This construction [was] agreeable to its primary etymology. [So, would] it not be the duty of the federal court to say that such laws [were] prohibited? [And would not] this go to the destruction and annihilation of all the citizens of the United States to enrich a few?" "[Under the Confederation,] if [Virginia] were called upon to pay twenty millions, shilling for shilling, or at the rate of one for forty, [her] legislature could 
refuse it, and remonstrate against the injustice of the demand. But [under the Constitution,] this could not be done; for direct taxation [was] brought home [under that document] to [every] man. The federal officer [would] collect immediately of the planters." "[And] as an express power [was] given to the federal court to take cognizance of [constitutional] controversies, and to declare null all ex post facto laws, [he thought] gentlemen must see there [was] danger, and that it ought to be guarded against."

When Mason had finished, Madison arose once more and repeated for a third time, what he had said about the first clause of Article VI. He said nothing more, however, about the "ex-post-facto" clauses. Instead, shifting his ground, he argued with some reason that Mason and Henry had exaggerated the amount which Virginia would have to pay. And he asked the delegates whether they "suppose[d] that [the Northern states would] agree to any system or alteration that w[ould] place them in a worse situation than before"; something, of course, which neither Mason nor Henry, in strictness, had suggested, so far as the Constitution was concerned. "Let us suppose," said Madison, "[that] this commonwealth was possessed of the same money that the Northern states have; and suppose an objection was made by them to its redemption at its real value-what would be the consequence? We should pronounce them to be unreasonable, and on good grounds." "Th[e] case"-which he seemed to abandon in these remarks, so far, at least, as the constitutional issues were concerned - "[was] so extremely plain that it was unnecessary to say as much [about it] as ha[d already] been said."

Mason nevertheless observed that he "was still convinced of the rectitude of his former opinion"; that the whole thing "might be put on a safer footing by three words"; that, "by [confining] $]^{26}$ the restriction of $e x$ post facto laws to crimes, it would then stand under the new government as it did under the old." To detract from the effect of these remarks, which must have seemed true to those who heard them, Randolph then again declared, and again without authority, that he "could not coincide with the construction put by [Mason] on ex post facto laws." The debate, for which, it seems clear, neither side was really prepared as to the "technical," "professional" meaning of "ex post facto Laws," then passed on to other matters. ${ }^{27}$

In seeking to evaluate the contentions which Madison and Randolph

${ }^{26}$ In the report of the debates in the Virginia Convention, this appears as "continuing." 3 Elliot, op. cit. supra note 22 , at $48 \mathrm{x}$. This, however, is plainly a mistake. The context calls for "confining" or some other word of equivalent meaning.

${ }^{27} 3$ Elliot, op. cit. supra note 22, at $473-81$ passim. 
made in these debates, it is relevant to consider that the meaning given, without demur, to the "ex-post-facto" clauses, in the convention of North Carolina, a little later in the summer, was in accord with the views of Mason and Henry and the writer in The Massachusetts Centinel. The matter came up when fears were expressed by the opposition there, that "the Constitution, the Laws of the United States which sh[ould] be in pursuance thereof, and the Treaties made, or which sh[ould] be made under the Authority of the United States," would, as "the supreme Law of the Land," invalidate North Carolina's existing issues of paper money. The uneasiness of the opposition upon this point grew, in part, from the "billsof-credit" and "legal-tender" prohibitions, in the Constitution itself; but, as we shall see, they also feared Congressional legislation relating to the subject.

Stephen Cabarrus, an advocate of adoption, spoke in answer to the fears first mentioned. "I contend," he said, "that the clause which prohibits the states from emitting bills of credit will not affect our present paper money. The clause has no retrospective view. This Constitution declares, in the most positive terms, that no ex post facto law shall be passed by the general government. Were this clause to operate retrospectively it would clearly be ex post facto, and repugnant to the express provision of the Constitution." This argument, if it was intended as more than one of psychological probability, based on the attitude of mind evinced in the "ex-post-facto" clauses, was of course unsound. Yet it is clear, from the nature of the statements which Cabarrus made, that he must have understood "ex post facto Laws" as including retrospective civil statutes. $\mathrm{He}$ concluded his remarks by observing that "every gentlemen must be satisfied, on the least reflection, that [North Carolina's existing] paper money w[ould] not be destroyed. To say that it w[ould] be, [was] a popular argument, but [it was] not founded in fact, in [his] opinion." He admitted that he "had [had his] doubts;; but on consideration, [was] satisfied."

The same, however, was not true of the opposition. Timothy Bloodworth, one of its leaders, though he intimated no doubt that "ex post facto Laws" comprehended retrospective civil statutes, "beg[ged] leave to ask if the payment of sums now due [would be] ex post facto." "W[ould] it be an ex post facto law," he persisted, "[for Congress] to compel the payment of money now due in silver coin? [And] if suit [should] be brought in the federal court against [a North Carolinian], for a sum of money, w[ould] paper money be received to satisfy the judgment?" Bloodworth went on to admit that North Carolinians, of course, were to "send [their] own gentlemen to represent [them in Congress], and that there [was] not the 
least doubt they w[ould] put that construction on [the Constitution] which w[ould] be most agreeable to the people they w[ould] represent." "But it behoves us to consider," he insisted, "whether they can do so if they would, when they mix with the body of Congress. [For] the Northern States are much more populous than the Southern ones. To the north of the Susquehannah there are thirty-six representatives, and to the south of it only twenty-nine." The North, he concluded, would outvote the South; and it followed that there was danger of constructions and acts, on the part of Congress, which would be hostile to North Carolina and its paper money.

Bloodworth was answered by James Iredell, who, ten years later, was to be one of three Justices of the United States Supreme Court to declare that "ex post facto Laws" were limited to criminal statutes only. But in the summer of $I 788$, he did not seem to entertain this view. The state paper-money prohibitions in the Constitution "c[ould] not," he said, "have the operation [that had been] contended for. There [was] nothing in the Constitution which affect[ed North Carolina's] present paper money. It prohibit[ed], for the future, the emitting of any, but it d[id] not interfere with the paper money now actually circulating in several states. [Instead,] there [was] an express clause [in the document] which protect[ed] it. [The clause] provide[d] that there sh[ould] be no ex post facto law. [And] this would be ex post facto, if the construction contended for were right, as $h a[d]$ been observed by another gentleman." Iredell concluded by insisting upon the complete unfairness of arguing against the Constitution, that it would be violated by Congress. "Abuse," he said, "m[ight] happen in any government. The only resource against usurpation [was] the inherent right of the people to prevent [it]. This [was] the case in all free governments in the world. The people w[ould] resist if the government usurp[ed] powers not delegated to it. [And North Carolina, like all the other states,] must run the risk of [such] abuse."28

The view of the "ex-post-facto" clauses, which Madison and Randolph urged in the Virginia Convention, Madison again urged in debate in the House of Representatives, in somewhat similar circumstances, in I790. He urged it in answer to attacks upon his proposal-a quite "unreasonable" proposal according to the views he had expressed to the Virginia Convention - that certain of the debts of the United States should not be paid to the holders thereof, in accordance with their original tenor. Theodore Sedgwick, of Massachusetts, had at once pointed out that a law for such a purpose would necessarily "have a retrospective operation" and,

${ }^{28}{ }_{4}$ Elliot, op. cit. supra note 22 , at I68-87, especially I84-85. 
hence, be void; and that "no ex post facto law could be more alarming than [one] by which the right of private property [was] violently invaded." William Loughton Smith, of South Carolina, likewise expressed the view that Madison's proposal was one for the making of "an ex post facto law, which was prohibited," he said, "in express terms," by the Constitution. And Fisher Ames, of Massachusetts, gave voice to sentiments which were similar.

The first attempt of Madison's group to answer this objection was made by James Jackson, of Georgia. Plainly recognizing the civil, as well as the criminal, application of the "ex-post-facto" clause, Jackson yet contended that Madison"s proposal was not within its coverage. "No law ha[d] yet passed," he said, "for funding the debt; [Congress, therefore,] ha[d] a right to fund as [they] please[d]." And it was relevant to remember that Congress "c[ould] not [in any event] compel subscription [under any funding proposal] without the holder's consent." This last consideration, certainly not wholly unpersuasive, was not, however, enough for the Virginians. For John Page, of that state, arose and argued that the use of "ex post facto Law" in the Constitution, was "conjunctive"positive - "with a bill of attainder." Whether his own recollection was at fault, or he hoped that that of his hearers would be, is uncertain. "Gentlemen torture[d] everything," he said, "in order to produce evidence against an act of justice." The "ex-post-facto" clause of the constitution "relate[d]," he flatly insisted, "to [bills of attainder] only and c[ould] have no reference to the object of the proposition before the House."

This foolish argument was immediately answered by Elias Boudinot, of New Jersey. "The language [of the Constitution was] unequivocal," he said; and he read the "ex-post-facto" clause to prove this fact: that it was insusceptible of an appositive interpretation. He pointed out, too, "the particular operation of the measure [which Madison had proposed]-as being retrospective to the fullest degree." So, it was, he concluded, "a most palpable violation of the Constitution."

The next speaker, Stone, of Maryland, also an opponent of the proposal which Madison had made, did not trouble to refer to the "ex-post-facto" clause, at all; and it is perfectly clear, both from his remarks and the general tenor of the remarks of others, that the House majority was opposed to Madison's proposal, whether the Constitution permitted it or not. Madison, nevertheless, came back to the constitutional point again, in the speech he delivered after Stone had finished. His proposal, he insisted, was entirely constitutional: "Ex post facto lazes relate[d] to criminal, not civil cases.". But, as in the Virginia Convention, no authority-not 
even one of the many "civilians," "all" of whom, Edmund Randolph had said, supported this view-was cited; and Blackstone, soon to be so much relied upon, in support of this view, was again not mentioned. Madison, instead, presented an argument which, there can be no doubt, he knew to be false: that "the Constitution itself required [his] definition [of 'ex post facto Laws'] by adding to a like restriction on the States, an express one against retrospective laws of a civil nature." 29 This misleading statement, made in his anxious desire to clear himself of the charge of proposing unconstitutional legislation, had reference, of course, to the "contracts" clause of the Constitution. ${ }^{30}$

The next evidence bearing upon the original understanding of the "expost-facto" clauses is found in various American judicial decisions from the early and middle I790's. The earliest of these was in the Virginia case of Turner v. Turner's Executrix, heard in the Court of Appeals of that state, in I792. No question under the Constitution was involved in the case, since the act in issue in it had been passed by the Virginia legislature before the Constitution took effect. ${ }^{3 \mathrm{x}}$ The case, nevertheless, is of considerable interest, because the court that decided it was presided over by Edmund Pendleton, who had also presided over the Virginia ratifying convention of $\mathrm{r} 788$, in which the arguments of Henry, Mason, Randolph, and Madison, quoted above, were made.

The case in question involved an act of the Virginia legislature, passed in 1787 , "to explain" certain earlier laws which that body had enacted. The question was as to the validity of this explanatory act, in its application to things done under the earlier acts before the explanatory act had been passed. The court held that it was not valid for such a purpose. "It is the business of the legislators," Judge Pendleton said, "to make the laws; and of the judges to expound them. Having made the law, the legislature have no authority afterwards to explain its operation upon things already

292 Annals Cong. Ir96, I205, I214, I220, I227, I24I, I249, I266 (I790); The [New York] Gazette of the United States (Feb. 20, 27, March 3, 1790), especially pages 358, 366 and 360 .

${ }^{30} 2$ Farrand, op. cit. supra note $I$, at $439-40,636,640 ; 4$ Ibid., 59. For a presentation of part of the evidence on this point, see a review, by the author hereof, of Wright, The Contracts Clause of the Constitution in $47 \mathrm{~J}$. Pol. Econ. 578 (1939).

${ }^{31}$ Statements are frequent, in the cases early in the nineteenth century, that, when the Constitution took effect, the states voluntarily repealed all past laws deemed to conflict in principle with the future prohibitions of the Constitution. See, for example, the statement of Johnson, J., in Ogden v. Saunders, 12 Wheat. (U.S.) 213, 278 (1827): "Everywhere, too, the principle was practically acquiesced in, that taking away the power to pass a law on a particular subject was equivalent to a repeal of existing laws on that subject." The cases mentioned at this point in the text show that the foregoing and other statements to the same effect can not be relied upon. They were generally used to introduce a spurious kind of "practical construction," by the states, in favor of "States' Rights.". 
done under it. They may amend as to future cases, but they cannot prescribe a rule of construction, as to the past. For a legislative interpretation, changing titles founded upon existing statutes, would be subject to every objection which lies to ex post facto lawes, as it would destroy rights already acquired under the former statute, by one made subsequent to the time when they became vested." ${ }^{32}$ Entertaining such views, it is of course not likely that Pendleton was much impressed with the arguments which James Madison and Edmund Randolph had made in the Virginia Convention. And ten years after the Turner case, he defined, "ex post facto laws" explicitly, in another case (which also did not "arise under the Constitution"), as "such [laws] as declare prior acts criminal, which were not so at the time they were done, or which either impair or give a new and important force to existing obligations or contracts, contrary to their situation at the time they were entered into." 33

This view of "ex post facto Laws" was also expressed in Den v. Gold$\operatorname{trap},{ }^{34}$ a New Jersey case decided in I795. Like the Virginia cases cited above, the case related to a statute passed before the Constitution took effect. "This act," said the New Jersey court, "strictly speaking, is ex post facto, and being penal"- that is,' in a civil sense- "so far as it respects precedent mortgages, [it] should not be extended beyond its manifest design." ${ }^{35}$ Later in the same year, or in the year following, another act of the New Jersey legislature, "passed in March I795," was held by the New Jersey Supreme Court "to be an ex post facto lawe, and as such unconstitutional and inoperative [in the particular case].? The case in which this decision occurred, was Taylor v. Reading. The case is unreported; but it was referred to circumstantially, by Chief Justice Kirkpatrick, in the reported New Jersey case of State v. Parkhurst, ${ }^{36}$ in 1802 . From the Chief Justice's remarks therein, it appears that the New Jersey statute in the Taylor case required certain "payments [theretofore] made in continental money [to] be credited as [if made in] specie." Since the New Jersey constitution contained, at the time, no "ex-post-facto" prohibition, the decision must have been made under the "ex-post-facto" clause relating to the states, which is contained in the national constitution. ${ }^{37}$

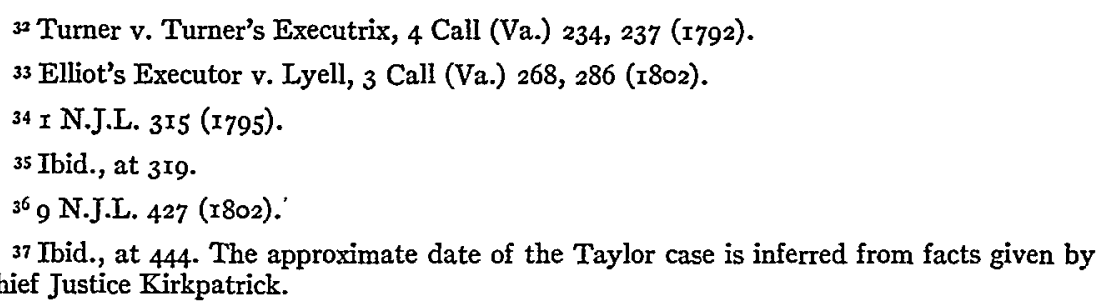


The foregoing New Jersey decision undoubtedly represents the considered professional view in the middle I79o's, as to what the "ex-postfacto" clauses of the Constitution covered..$^{38}$ This fact is interestingly confirmed by the remarks on the subject, made by Justice William Paterson, of the United States Supreme Court, in the case of Van Horne's Lessee v. Dorrance, ${ }^{39}$ which he decided on circuit, in Pennsylvania, in April I795. The case grew out of the well known controversy of the I780's, between the states of Pennsylvania and Connecticut, over the Wyoming valley lands in the former state. Connecticut people had settled on those lands without authorization from Pennsylvania. Dorrance, the defendant in the case, was one of these settlers, and in possession of the land which was in litigation in the case. The owner of the land, under an antecedent title deriving from the former proprietaries of Pennsylvania, was Van Horne. In March $\mathrm{I}_{7} 87$, the Pennsylvania legislature had passed an act to settle the many individual controversies over the Wyoming lands, of which the dispute between Van Horne and Dorrance was an example. The act provided that the Connecticut settlers should prefer their claims to certain commissioners; that they should offer certain proofs; and that if the commissioners, on the basis of these proofs, should confirm their claims in accordance with the act, they should be entitled to keep the lands on which they were settled. Disappointed Pennsylvania claimants were to receive other lands in compensation.

Various of the Connecticut claimants at once preferred their claims under the act in question; but before their claims could be passed upon by the state's commissioners, the act of $I 787$ was suspended. The act of suspension was passed by the Pennsylvania legislature, in March 1788 , which was before the Constitution was in force. Then, in $x 790$, the act of $I_{7} 87$ was definitely repealed. Van Horne, thereupon, brought action against Dorrance to recover his land; and Dorrance, counting upon the fact that the repealing act was passed after the Constitution took effect, defended on the ground that the repealing act was both an "ex post facto Law" and a "Law impairing the Obligation of [a] Contract" made with him, he said, by the state of Pennsylvania, when the act of $x 787$ had been passed. At the trial, Justice Paterson rejected both these defenses and gave judgment for the plaintiff.

In reference to the contention that the repealing act was an "ex post facto Law," the Justice began by inquiring "what [was] the fact"-that

${ }^{38}$ See also the argument of William Rawle, of Philadelphia, in Warder v. Bell, $x$ Yeates (Pa.) 531, 532 (1795).

${ }^{39} 2$ Dall. (U.S.) 304 (r795). 
is, what was "the fact" after which the law was "passed," that made it void as an "ex post facto Law" under the Constitution. The passing of the original confirmatory act of 1787 could not, Justice Paterson thought, be such a "fact." "[For] if making a law [were] a fact, within the words of the constitution, then no law, when once made, c[ould] ever be repealed." "Some of the Connecticut settlers," he agreed, "[had] presented their claims to the commissioners, who [had] received and entered them, [before either the suspending or the repealing act had been passed]. These [were] facts. But [were] they facts of any avail?" The Justice's answer was that they were not. "Whether done or not done, they $\mathrm{l}[\mathrm{eft}]$ the parties just where they were. They create[d] no interest, affect[ed] no title, change[d] no property; when done, they [were] useless and of no efficacy. Other acts were necessary to be performed, but before the performance of them, the law [of $\mathrm{I} 787$ ] was suspended and then repealed." In these circumstances, the repealing act was not an "ex post facto Law," void under the Constitution. Such was the judgment; and such the reasoning of the Justice to support it. From the nature of the latter, it seems perfectly clear that Justice Paterson assumed, without the slightest doubt or question, that "ex post facto Laws" comprehended retrospective civil, as well as criminal, statutes..$^{40}$ Yet, three years later, he was one of the three Justices of the Supreme Court of the United States, who announced to the country the contrary view.

The foregoing being the state of the American judicial decisions on the subject of "ex post facto Laws," in the middle I 79o's, there hardly can be a doubt that the decision of the United States Supreme Court in Calder v. Bull $^{4 \mathrm{x}}$ came to the profession, in $\mathrm{I} 798$, as something of a surprise. For, in that case, three of the participating Justices declared, as already indicated, that the "ex-post-facto" clauses of the Constitution had no reference to anything but criminal statutes. Two of these Justices were William Paterson and James Iredell, who, as we have just seen, were pretty plainly on record as holding the contrary view. The third Justice who helped to make this decision, was the one Anti-Federalist member of the Court, Samuel Chase, of Maryland.42 The remaining Justice who sat

$4^{0} \mathrm{Ibid}$, at 3 $\mathrm{x} 9$.

$$
{ }^{4} 3 \text { Dall. (U.S.) } 386 \text { (I798). }
$$

42 Chase was not a Federalist, as so often has been erroneously stated. See, for example, Warren, New Light on the Fistory of the Federal Judiciary Act of 1789,37 Harv. L. Rev. 49, 73 (I923). He had, instead, been one of the ringleaders of the opposition to the Constitution, in Maryland, in 1787 and 1788 . In spite of his record, he was put on the Supreme Court, by Washington in $I 796$, in the hope, presumably, that his allegiance and real abilities might thereby be enlisted in the service of the new government. The move was not a success. Chase was no sooner in office than he began to set afloat, in his opinions, a great mass of Anti-Federalist sophistries; views which had never been heard from a Supreme Court Justice, before his addi- 
in the case, Cushing, of Massachusetts, was apparently of the opinion (which was certainly correct) that the point his three brethren were deciding, was not involved in the case; and therefore declined to discuss it.

Calder v. Bull came to the Supreme Court from Connecticut. In accordance with the long-established customary constitution of that state, ${ }^{43}$ the legislature thereof had granted, upon petition from a party to certain probate proceedings there, a new hearing in the probate court, after the right of appeal to the ordinary courts for the obtaining of such a rehearing was barred by the lapse of time. To a correct evaluation of this action of the Connecticut legislature, it is necessary to understand that, under the customary constitution of the state, the right of appeal from the original probate proceedings, to the legislature as the highest judicial tribunal of the state, was not barred by the lapse of time when the petition to that body was presented. The legislature's exercise of its long customary reviewing power in the Calder case was, therefore, very plainly not the "passing" of "an ex post facto Law," even if the "ex-post-facto" clauses of the Constitution were taken as they actually were written. This was the view of the case which Cushing, the only New England Justice who participated in the case, presented. The beneficiary under the original probate proceedings contended, nevertheless, that the action of the Connecticut legislature had been the "passing" of "an ex post facto Law"; and the other three Justices, apparently eager to settle this point (which the case did not involve), and to settle it contrary to what, we have seen, was the then prevailing view, decided that the action of the Connecticut legislature-taking it to be what it clearly was not: the "passing" of "a law"was nevertheless not obnoxious to the "ex-post-facto" clause of section Io, because that clause and the similar clause in section 9 had nothing to do with anything but criminal matters.

The principal opinion in the case, that of Samuel Chase, was delivered with a great show of confidence, and a great parade of apparent authorities; yet, as a younger Justice of the Supreme Court was to show, in $1829,{ }^{44}$ his authorities will not bear the slightest examination. In these

tion to the Court. Chase's opinion in Calder v. Bull is no exception in this respect, and not one of the other Justices in the case agreed with all of what he had to say. The notion that Chase was a Federalist has probably arisen from the personal animosity that existed between him and Thomas Jefferson. The bad feeling between these two led Chase, in effect, to "campaign" from the bench against Jefferson in I800; and this, after Jefferson finally obtained the Presidency, in the following year, eventually led to Chase's impeachment.

43 Connecticut had no written constitution until much later.

${ }_{14}$ See the memorandum of Justice William Johnson upon the subject, printed in the rear of the first edition of the second volume of Peters' United States Reports. The memorandum is discussed in the text hereof at a later point. 
circumstances, it might be supposed that the two concurring Justices, Iredell and Paterson, who were already on record in favor of the contrary view, would have shown some evidence of embarrassment over their change of position. Iredell, however, apparently did not regard his pronouncements in the North Carolina Convention, of ten years before, as a matter of much consequence; at any rate, he made no allusion to his former views, either openly or covertly. Paterson, on the other hand, whose opinion in the case of Van Horne's Lessee v. Dorrance was either about to be, or had just been, published, ${ }^{45}$ seems, understandably, to have felt somewhat more disturbed. And, so, having averred his belief that the Federal Convention "understood and used the words ['ex post facto Laws,' in the Constitution,] in their known and appropriate signification, as referring to crimes, pains, and penalties, and no further," Paterson went on to say that he himself "had [had] an ardent desire to have extended the provision in the constitution to retrospective laws in general." These words, sometimes taken, it would seem, to refer to Paterson's part in the Federal Convention, ${ }^{46} \mathrm{can}$, in fact, have had no reference to that subject; for Paterson left the Federal Convention before the question of "ex-postfacto" prohibitions was taken up; had had, therefore, no part in the proceedings respecting them; and possessed no special knowledge on the subject. ${ }^{47}$ His words, therefore, were clearly in the nature of an apology for the inconsistency of his views in the Calder case, with those he had so plainly entertained in Van Horne's Lessee v. Dorrance.

To understand what lay behind this inconsistency of William Paterson, and that of his associate, Iredell; and to see the reason for the decision which they and Samuel Chase so needlessly made upon such flimsy grounds, it is necessary to know something of the conditions in the country when Calder v. Bull was decided, and something of what was going on, at the time, in Congress. The first fact of moment is that, although the Constitution had authorized Congress to enact a uniform bankruptcy law, no such law had been enacted by that body, when the government was organized in 1789 . A committee, indeed, had been appointed in the House, to draw up such a law, as early as June I of that year; but in the following February, the subject had been laid on the table, "till the public debt should be funded and banks established, without which it [would be] diff-

45 Dallas's second volume, in which the Dorrance case appears, was published at some time in 1798 .

${ }^{4} 6$ This seems to be the meaning of a note, not altogether clear in its intent, which is found in Wright, The Contract Clause of the Constitution 33 (1938).

${ }^{47} 3$ Farrand, op. cit. supra note 1 , at 73, 589; 4 Thid., at 72, 73 . 
cult to conceive," it was said, "how arrangements could be made to facilitate the payments of debts or the operation of such a law." ${ }^{48}$

Thereafter, the matter remained more or less in abeyance, until after the "bubble" of speculation in scrip had burst, in I792, with a resulting financial panic, of some proportions, for the country. After this, a bill was reported, late in the year, in Congress; but received from that body no serious consideration. The same fate met several other bills of a similar kind, which were proposed, from time to time, over the next four years. The amount of material on these bills in the Annals of Congress is, as usual, not very great; yet it is sufficient to show that there was a strong opposition, which pursued a persistent policy of obstruction and delay. It is also clear that the opposition, in the main, was a Southern opposition, though it was abetted by a certain amount of support from the back-country regions of the North. ${ }^{49}$

The basis of this Southern and back-country Northern opposition was the fact that the proposed bankruptcy system would have made all the property of debtors, including their lands, available for the payment of their debts. In the slave-holding Southern states, committed, as those states were by the slavery system, exclusively to agriculture, the planter majority saw to it that various obstacles were thrown in the way of debtcollection from the class to which they belonged, and somewhat similar obstacles, favorable to agriculture, existed in certain of the Northern states as well. The proposed national bankruptcy act threatened these privileges, which lay, of course, at the bottom of many a mercantile failure of the time; and hence the opposition which arose among the representatives of the Southern states, and of the back-country North, to the proposed national bankruptcy system..$^{50}$

The danger to the planter class was observed at once by Thomas Jefferson, when the first of the above-mentioned bills was reported in Congress, in I792. "A bankrupt bill is brought in," he wrote revealingly about a fortnight later, "in such a form as to render almost all the landholders South of [Pennsylvania] liable to be declared bankrupts." "It assume[d] a right," said Jefferson, "of seizing and selling lands." This, of course, he at once perceived to be outrageously unconstitutional; and, in addition, he saw, with distinctness, that it was most unwise, since "all

$4^{8}$ I Annals Cong. 4r $\%$, Iro5-6 ( 1789$)$.

${ }^{49} 3$ Annals Cong. I66, 708, 74I (r792); 4 Tbid., at r42, 256 (I794); 5 Ibid., at r49, 240 (1796); 6 Ibid., at $1739-40$ (1797).

${ }^{50}$ The debate in 9 Annals Cong. $2649-77$ ( 1799$)$, though not in all respects completely candid, gives a good insight into the essential nature of the politics involved. 
laws" ought to be made "with a view," he thought, to the welfare of the class he pathetically described as "the poor husbandman."

Whether or not Jefferson was right in his views, "the poor husbandman" did manage to gain sufficient support, especially among the Southern states (other than South Carolina), to block any bankruptcy legislation. The country in general quickly recovered from the effects of the panic of 1792 , and the support for the bankruptcy bill probably, in consequence, fell off. In $\mathrm{x} 796$, however, another financial crash took place, which brought down a great structure of credit that had been reared, in the year preceding, largely on land speculation; failures were numerous; and the demand for bankruptcy legislation again became urgent. The desire, of course, was to extend such a law to existing debts, and thereby to afford relief to the many debtors who were then being held in jail or were prevented, by their hopeless burdens of indebtedness, from engaging again in business..$^{52}$

The proposal to extend relief to such persons was met, however, by the statement that it was now too late to do so, since a bankruptcy act applying to them was forbidden, it was said, by the "ex-post-facto" clause of the ninth section of Article I. ${ }^{33}$ As this view was in plain accord with the long customary meaning of the words of this clause, and with what, everyone must then have known, had been its actual purpose, it is not surprising that this view had weight. In the bill that was reported, a provision was accordingly made, that "no certificate granted in pursuance of th[e] act sh[ould] be available or effectual to discharge any debts contracted prior to the date of th[e] act, but [that] the same, or so much thereof as sh[ould] not be satisfied out of the effects of the bankrupt, sh[ould] be recoverable in like manner as they might have been if th[e] act had not been made." ${ }_{54}$ This was the state of this legislation, long pending in Congress, when Calder v. Bull was decided in August 1798 .

The foregoing facts constitute the general background of that case: a bankruptcy law, when the case was decided, had still not been obtained, in spite of nine years of effort, and the need for such a law existed in an extreme degree. To understand, however, just how pressing the necessity

${ }^{51} 7$ The Works of Thomas Jefferson I93, I94, I96, I97, I98 (Federal ed., I905).

527 Annals Cong. $643,644,692,786,788,796,797,970$ (I797); 8 Ibid., at 2426, 244I, 2465' $2489,255^{2}, 255^{6}, 2577,2582,2649,2656,2677$ (1798).

53 There seems to be no direct record of this in the Annals of Congress; but James A. Bayard, of Delaware, referred to the matter in a speech in Congress in I799. The statement in the text is based on his statement. See 9 Annals Cong. 2579 (I799).

549 Annals Cong. 2577-79 (1799). 
for such legislation must then have seemed, especially to men, like the Justices, who were concerned in the Government, it is necessary to know that the financial debacle of 1796 had carried down with it many men who had previously participated prominently in the Government, and, also, in the American Revolution. Thus, in the very city where the Court was sitting, Robert Morris, the financier of the Revolution, an important member of the Federal Convention, and very lately a member of the United States Senate, was then confined in a debtor's prison. Once reputed to be the wealthiest man in the country, Morris had been arrested and thrown into prison, in the preceding February, upon the suit of a small creditor whom he could not pay. ${ }^{55}$ His case, moreover, was only the most prominent and notorious among a great host of others; and to the Supreme Court, very likely, it was not by any means the case which distressed them most. For one of the Court's own members was, if anything, in a situation even worse.

The individual in question was James Wilson, of Pennsylvania. Signer of the Declaration of Independence, member of the Federal Convention, and the chief preliminary draftsman of the Constitution, Wilson had been an Associate Justice of the United States Supreme Court, from the beginning of the Government in I789. Caught with illiquid assets in the general debacle of 1796 , Wilson, in the summer of the following year, had been obliged to remove with his family, from his home in Philadelphia, to Burlington, New Jersey, in order to avoid imprisonment for debt. So close at hand, however, he was still not safe, and an arrangement was made among the Justices, that Wilson should ride circuit in far-away North Carolina. He had arrived there for that purpose, early in 1798 , in the utmost mental distress. "Hunted like a wild beast," to use his own words, he had finally broken down and was totally unfit for his judicial duties. He stayed, for a considerable time, at the home of his brother Justice, James Iredell, in Edenton, but had, of course, to be left behind when it came time for the Supreme Court's own sessions at Philadelphia, then the seat of the national government. And Wilson died in Edenton, only a few weeks later, of "a violent nervous fever," shortly after his brethren had decided, in effect, in the state probate case providentially come from Connecticut, that national bankruptcy relief for such men as their sick and unfortunate associate was not in violation of the Constitution he had helped to make..$^{56}$

ss See r3 Dictionary of American Biography 223 (1934).
${ }^{6}$ See 20 Dictionary of American Biography 330 (1936). 
So, as the reader can see, George Mason's predictions were very soon verified. The ex-post-facto clause fell on the very first test-indeed, it fell in anticipation of that test-upon the precise matter at which it unquestionably had been directed. It remains to be said that the proviso above mentioned, which had been intended to exempt all pre-existing debts from discharge under the act that was pending in Congress when the case was decided, was expunged from that act, in the following January; ; $^{57}$ and though an act was not finally gotten through Congress, until I80o, the act then passed was retrospective, as well as prospective, in its operation..$^{58}$ So, the purpose of the decision in Calder v. Bull was eventually achieved.

The contemporary opinion of the case may be inferred, however, from the fact that the bankruptcy act of I800 was still being attacked in Congress as an unconstitutional "ex post facto Law" when the act was repealed in 1803.59 Further evidence to the same effect may be seen in the sardonic comment on the case, made by James Madison's old college friend, Hugh Henry Brackenridge, in $18 \mathrm{I} 2$. The comment is found in Brackenridge's opinion in Stoddart v. Smith, ${ }^{60}$ a case decided by the Supreme Court of Pennsylvania, in that year. "I take notice," he said, "of the language of the Court of the United States, as confining ex post facto to a criminal case. It is an idea purely American, and not the worse for that, but it is incorrect. Ex post facto law, ex jure post facto, translated 'ex post facto law,' embraces civil contracts as well as criminal acts. The poena and the action, ex jure post facto, or arising on an act done or a contract made before the law was passed, are both embraced by this term." And, then, being by that time a good Jeffersonian, Brackenridge added, so as not to make trouble, on the "contracts" clause, that "our constitutions use[d] the phrase ex post facto law, or law impairing contracts"; but that "they mean $[t]$ no more than to specify under the idea of impairing contracts, a kind of ex post facto law, which was embraced under the general term ex post facto." $6 x$

Besides the foregoing materials, there is a letter of Thomas Jefferson's, from $18 \mathrm{I}_{3}$, which, in a queer way, also provides evidence upon the point in question. Jefferson, of course, was getting old by that time, and seems. to have begun to forget in the queer, inverted way that old men do, with the result about to be noted. It appears from his letter, which was written

\footnotetext{
579 Annals Cong. 2577-79 ( 7799 ).

$5^{8} 2$ Stat. $19\left(1800-x_{3}\right)$.

59 I2 Annals Cong. 55I (1803).
}

${ }^{60} 5$ Binney (Pa.) 355 (I812).

$6 x$ Ibid., at 370 . 
to one Isaac M'Pherson, that a certain Evans had had a patent for some machinery. The term of the patent ran out, and Evans applied for a renewal. Congress, however, at first declined to grant the renewal and, then, after a rather long interval, did so. In the meantime, Jefferson's correspondent had built one of the machines which the patent would have covered, had there been any patent when he built it; but because there was none, he counted upon being able to use his machine royalty-free. When Evan's patent was renewed, Congress, however, made its renewal retroactive to the date of the termination of Evan's initial patent; and M'Pherson, in consequence, was obliged to pay royalties to Evans, contrary to his expectations. He thought this very unjust, and Jefferson agreed with him. "Every man," said Jefferson, "should be protected in his lawful acts, and be certain that no ex post fact law shall punish or endamage him for them. [And a man was] endamaged," Jefferson thought, "if [he was] forbidden to use a machine lawfully erected at considerable expense, unless he w[ould] pay a new and unexpected price for it." The action of Congress, Jefferson therefore considered unwarranted. And reflecting upon this fact, he added the following comment: "The sentiment that ex post facto laws are against natural right, is so strong in the United States, that few if any of the state constitutions have failed to proscribe them. The federal constitution, indeed, interdicts them in criminal cases only; but they are equally unjust in civil as in criminal cases, and the omission of a caution which would have been right, can not justify the doing what is wrong." It seems evident, from this comment, that Jefferson, then an aged man, had forgotten, when he wrote his letter, the then relatively recent facts about the content of the Constitution, and what had happened to it; but he had, it appears, no doubt at all about the more ancient fact, which he had undoubtedly known from his early manhood, that "ex post facto Laws" were not limited to criminal cases only ${ }^{62}$

It remains to be added that the true basis of the decision in Calder $v$. Bull was apparently soon forgotten. For, within thirty years, a younger Justice of the Supreme Court, as already intimated, was laboring hard to prove that his predecessors, in the Calder case, had made, what he seems to have supposed, was an error. The Justice in question was William Johnson, of South Carolina. In Ogden v. Saunders, ${ }^{63}$ in 1827 , and, again, in Satterlee v. Mattheweson, ${ }^{64}$ in 1829 , he sought to persuade the Court to repudiate the view that the "ex-post-facto" clauses of the Constitution refer

626 The Writings of Thomas Jefferson I75-76 (Washington's ed., I86I).

${ }^{6}{ }^{1}$ 2 Wheat. (U.S.) $2 \times 3,286$ (1827). ${ }_{64} 2$ Pet. (U.S.) 380,416 (I829). 
to criminal statutes only. This was necessary, he said, to cover the case of contracts "erected" by a state, on the basis of past acts which had not given rise to a contract when the acts had been done. In a memorandum attached to the Satterlee case, Johnson, therefore, dissected the reasons, one by one, which had been given by the majority Justices in the Calder case, for the position they had therein taken. There can be no doubt that he proved those reasons to be imaginary. And he also showed that an interpretation of the "ex-post-facto" clauses, and certainly of that which applied to Congress, was in no way necessary to the decision. ${ }^{65}$ The "error" of the case has, nevertheless, persisted; and the "ex-post-facto" clauses, at the present day, are completely meaningless, except for a purpose for which they were hardly needed.

$6_{5} 2$ Pet. (U.S.) 68I (Ist ed., I829). 